\title{
Preparasi Kromosom Fase Mitosis Markisa Ungu (Passiflora edulis) Varietas Edulis Sulawesi Selatan
}

\author{
NURUL MUHLISYAH ${ }^{1}$, CUT MUTHIADIN ${ }^{1}$, BAIQ FARHATUL WAHIDAH ${ }^{1}$, \\ ISNA RASDIANAH AZIZ ${ }^{1}$ \\ ${ }^{1}$ Jurusan Biologi, Fakultas Sains dan Teknologi, UIN Alauddin Makassar \\ Jl. Sultan Alauddin 36 Samata, Kab. Gowa 92113 \\ email: cutmuthia82@gmail.com
}

\begin{abstract}
Passion fruit (Passifloraceae) was derived from tropical South America. Kind of passion fruit that widely cultivated in South Sulawesi is purple passion fruit (Passiflora edulis). This study aimed to observe the activity of Passiflora edulis chromosome at different stages of cell division and observed active mitosis time. The study was conducted by using exploratory descriptive study and obtained results a mitotic on Passiflora edulis occurs at 09.00 until $15.00 \mathrm{pm}$. Prophase seen in 5 minute after observation, prometaphase in 80 minute after the first observation, metaphase in 154 minutes after the first observation, anaphase in 227 minutes after the first observation, and telophase in 317 minutes after the first observation.
\end{abstract}

Keywords: Chromosome, Mitosis, Passiflora edulis, Purple Passion Fruit

\section{PENDAHULUAN}

Indonesia merupakan wilayah tropis, beriklim basah. Daerah ini memungkinkan tumbuhnya berbagai macam tumbuhan dengan subur. Berbagai macam buah-buahan, seperti durian, rambutan, lengkeng tumbuh liar di hutan Sumatera dan Kalimantan. Namun, masih terlalu sedikit yang dibudidayakan. Padahal buah-buahan tersebut merupakan harta alam yang sangat berharga (Sunarjono, 2008).

Perkembangan industri pengolahan hasil buah-buahan merupakan peluang yang cukup besar untuk meningkatkan produksi buahbuahan sebagai bahan baku industri pengolahan tersebut. Di Indonesia, perkembangan industri pengolahan hasil buahbuahan cukup pesat. Beberapa industri pengolahan hasil buah-buahan yang sudah beroperasi di Negara kita adalah industri pengalengan buah-buahan, industri minuman sari buah, dan industri jus. Luas wilayah pemanenam buah markisa di Sulawesi Selatan cenderung terus meningkat, dari $1.304,70$ ha pada tahun 1990 menjadi $2.247,26$ ha pada tahun 1995, atau meningkat rata-rata sebesar $14 \%$ per tahun. Produktivitas buah markisa juga meningkat dari 4,04 ton/ha pada tahun 1990 menjadi 17,28 ton/ha pada tahun 1995.
Secara umum, produksi markisa di Sulawesi Selatan pada tahun 1990-1995 meningkat dari 5.270 ton menjadi 38.824 ton atau sekitar $127,3 \%$ per tahun. Di Brastagi, Sumatra Utara pada tahun 1998 terdapat luas area tanaman markisa 1.274 ha dengan produksi 55.000 ton (Rukmana, 2003).

Tanaman markisa (Passifloraceae) berasal dari Amerika Selatan yang beriklim tropis. Saat ini terdapat lebih dari 400 spesies tanaman markisa (Passifloraceae) dan 50 spesies diantaranya dapat dikomsumsi sebagai buah. Tanaman markisa yang banyak dibudidayakan secara komersial markisa ungu (Passiflora edulis $f$ edulis.Sims) dan markisa kuning (Passiflora edulis fflavicarpa Degner). Nama lain dari buah markisa di luar negeri adalah passion fruit, granadilla, purple granadilla fruit atau merajuca.

Tanaman markisa dikembangkan di beberapa tempat di Indonesia antara lain di Sulawesi Selatan, Sumatra Utama, Sumatra Barat dan Lampung. Jenis markisa yang dikembangkan di Sulawesi Selatan dan Sumatra Utara adalah markisa ungu (Passiflora edulis) sedangkan di Sumatra Barat pada umumnya adalah markisa kuning (konyal) untuk dikomsumsi secara langsung (Sulistyo, 2003). 
Markisa asam berkulit buah ungu merupakan bahan baku utama industri pengolahan sari buah markisa dan sirup konsentrat. Markisa ini banyak dibudidayakan di Sulawesi Selatan, yaitu Kabupaten Gowa, Sinjai, Tator, Enrekang, dan Polmas, dan di dataran tinggi Sumatera Utara yang meliputi Kabupaten Karo, Simalungun, Dairi, dan Tapanuli Utara. Markisa asam berkulit buah kuning merupakan salah satu jenis markisa yang tidak banyak dibudidayakan, namun dapat tumbuh di dataran rendah. Walaupun jenis ini tidak banyak dibudidayakan di Indonesia, namun disebagain besar Negara penghasil markisa, kultivar-kultivar markisa kuninglah yang umum dibudidayakan (Zee dan Menukat 1995, Verheij dan Coronel 1997, Rojas 1997). Markisa jenis konyal atau markisa manis memiliki rasa yang manis dan menyegarkan, enak dikomsumsi sebagai buah segar. Markisa ini banyak diusahakan di daerah Alahan Panjang, Kabupaten Solok, Sumatera Barat. Jenis konyal mempunyai potensi pengembangan dan prospek pasar yang cerah. Pasar buah segar markisa konyal antara lain Jakarta, Bandung, Pekambaru, dan Batam (Karsina dkk, 2007).

Siklus sel adalah periode dari permulaan satu pembelahan menuju ke permulaan yang lainnya, sedangkan reproduksi seluler adalah proses perputaran dari pertumbuhan mitosis dan pembelahan sel. Siklus sel terdiri dari interfase dan mitosis. Interfase itu sendiri terdiri dari tiga fase $\left(\mathrm{G}_{1}, \mathrm{~S}\right.$, dan $\left.\mathrm{G}_{2}\right)$. Sedangkan mitosis terdiri dari 5 fase yaitu profase, prometafase, metafase, anafase dan telofase. Mitosis adalah proses pembagian genom yang telah digandakan oleh sel ke dua sel identik yang dihasilkan oleh pembelahan sel. Mitosis umumnya diikuti oleh sitokinesis yang membagi sitoplasma dan membran sel. Proses ini menghasilkan dua sel anak yang identik, yang memiliki distribusi organel dan komponen sel yang sama, serta bertujuan untuk mempertahankan pasangan kromosom yang sama melalui pembelahan inti secara berturut-turut. Proses mitosis terjadi di dalam sel somatik yang bersifat meristematik, yaitu sel-sel yang hidup terutama sel-sel yang sedang tumbuh (ujung akar dan ujung batang)
(Novel dkk, 2010). Dengan demikian, perlunya mempertahankan keberadaan tanaman markisa ungu (Passiflora edulis) varietas edulis sebagai tanaman yang banyak terdapat di daerah Sulawesi Selatan sebagai buah yang memiliki prospek. Karena itu, perlu adanya pelestarian tanaman markisa dengan mengetahui informasi morfologi dan genetika tanaman, khususnya kromosom.

\section{METODE}

Pengambilan Bahan. Lokasi pengambilan bahan markisa ungu varietas edulis di Dusun Kalebarembeng, Kecamatan Bontonompo, Kabupaten Gowa.

Perkecambahan dan Pemotongan Ujung Akar. Proses perkecambahan benih markisa dilakukan dilaboratorium Mikrobiologi Universitas Islam Negeri Alauddin dengan menggunakan medium tanah dan aquadest. Setelah tumbuh akar dengan panjang sekitar $0,5 \mathrm{~cm}$, langkah selanjutnya adalah proses pemotongan ujung akar, dimana akar tersebut dipotong sekitar $3 \mathrm{~mm}$, dengan waktu pemotongan dimulai pada pukul 08.00 sampai pukul 12.00 WITA dengan interval waktu satu jam yang bertujuan untuk mengetahui waktu mitosis dari markisa.

Pembuatan sediaan. Pembuatan sediaan atau pembuatan preparat pada penelitian ini dengan menggunakan metode Squash (Jahier dan Tanguy, 1996) yang terdiri dari: (1) Tahap Fiksasi. Dilakukan dengan memotongan ujung akar yang masih muda kemudian akar tersebut dimasukkan ke dalam botol flakon. Langkah selanjutnya adalah dilakukan fiksasi dengan menggunakan larutan asam asetat glasial $45 \%$ (45 $\mathrm{ml}$ asam asetat glasial ditambahkan $55 \mathrm{ml}$ akuades) dengan waktu 15 menit pada suhu $4^{\circ} \mathrm{C}$. kemudian, potongan ujung akar tersebut dicuci dengan menggunakan akuades sebanyak 3 kali pengulangan. Fiksasi dilakukan dengan tujuan untuk mempertahankan komponen dari sel-sel markisa sehingga tetap dalam keadaan hidup. (2) Tahap Maserasi. Pada tahap maserasi potongan ujung akar yang telah difiksasi serta dicuci bersih selanjutnya dilakukan proses maserasi dengan menggunakan larutan $\mathrm{HCl}$ $1 \mathrm{~N} \quad(1 \mathrm{ml}$ asam klorida ditambah $11 \mathrm{ml}$ 
akuades) kurang lebih 11 menit dengan suhu $55^{\circ} \mathrm{C}$ dalam inkubator. Kemudian potongan ujung akar tersebut dicuci dengan akuades sebanyak 3 kali. Tahap maserasi dilakukan dengan laruran HCL bertujuan untuk melisiskan lamela tengah. (3) Tahap Pewarnaan. Proses pewarnaan dilakukan pada bagian ujung akar yang telah dimaserasi dan dibersihkan. Selanjutnya adalah tahap pewarnaan dengan menggunakan larutan aceto orcein 1\% (1 gram orcein yang dilarutkan dalam $100 \mathrm{ml}$ asam asetat $45 \%$ ) selama 20 menit pada suhu kamar. Pewarnaan dengan larutan orcein bertujuan untuk pewarnaan kromosom. (4) Pemencetan. Proses pemencetan dilakukan setelah potongan ujung akar tersebut diwarnai. cuplikan dari ujung akar tersebut selanjutnya diletakkan pada gelas preparat namun sebelum ditutup dengan gelas penutup terlebih dahulu ditetesi gliserin, langkah selanjutnya adalah dilakukan proses pemencetan (squash) dengan menggunakan ujung pensil. Kemudian bagian tepi gelas penutup tersebut diberi kuteks yang bertujuan agar bagian tepi gelas penutup melekat dengan baik serta diberi label. Selanjutnya preparat kromosom tersebut disimpan di lemari pendingin pada suhu $4^{\circ} \mathrm{C}$ sampai waktu pengamatan. Squash bertujuan untuk menipiskan sel, agar sel menyebar.

Pengamatan dan Pemotretan. Preparat yang telah diperoleh kemudian diamati dibawah mikroskop dengan menggunakan mikroskop binokuler "Prima Star Ziess". Selanjutnya mengamati dibawah mikroskop fase-fase mitosis (Profase, Prometafase, Metafase, Anafase dan Telofase).

\section{HASIL}

Berdasarkan dari hasil penelitian "Preparasi Kromosom Fase mitosis Markisa Ungu (Passiflora edulis) varietas edulis Sulawesi Selatan" yang dilakukan dengan menggunakan jenis penelitian deskriptif eksploratif, telah diperoleh hasil sebagai berikut:

Tabel 1. Fase Mitosis pada akar markisa ungu (P. edulis)

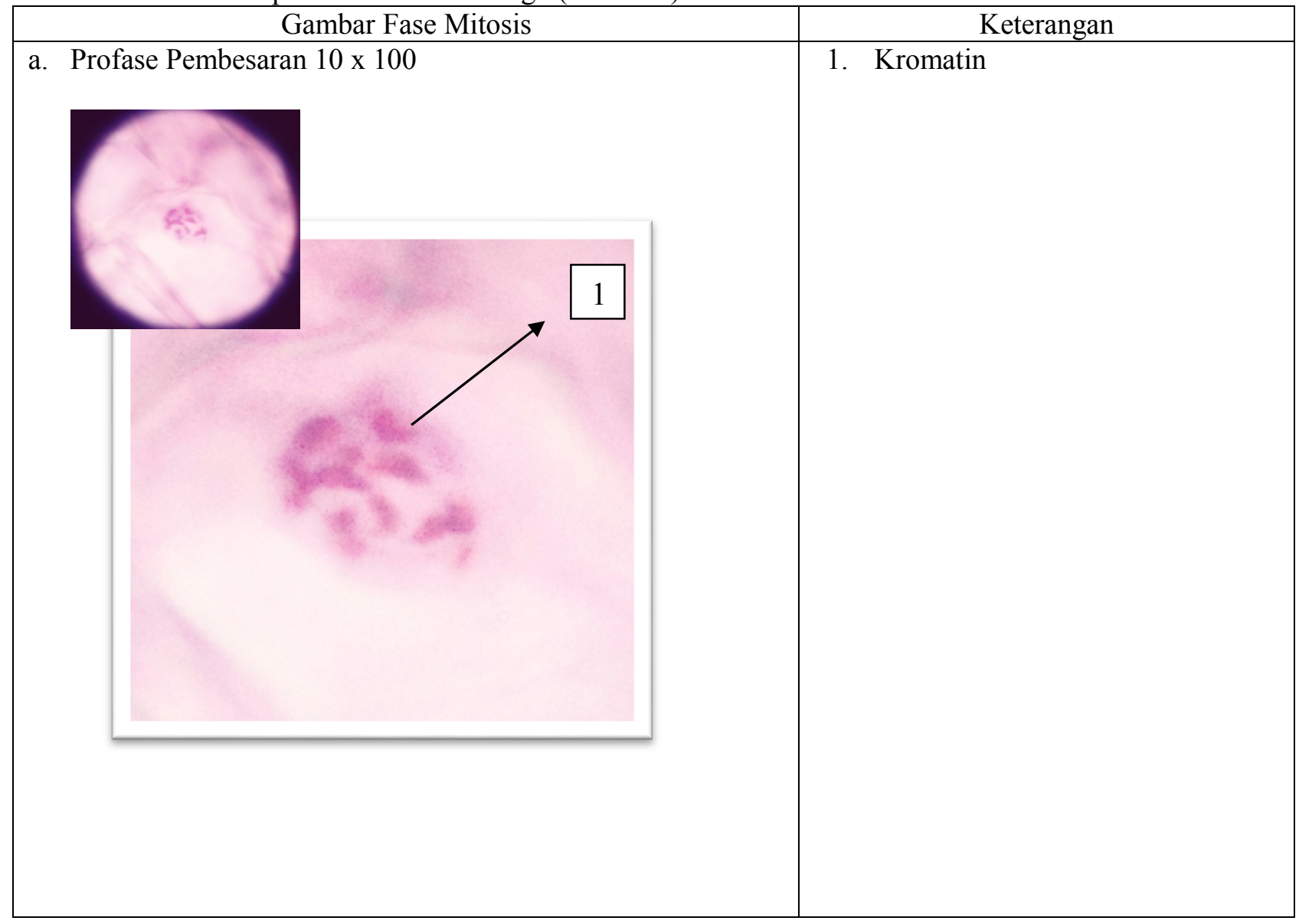




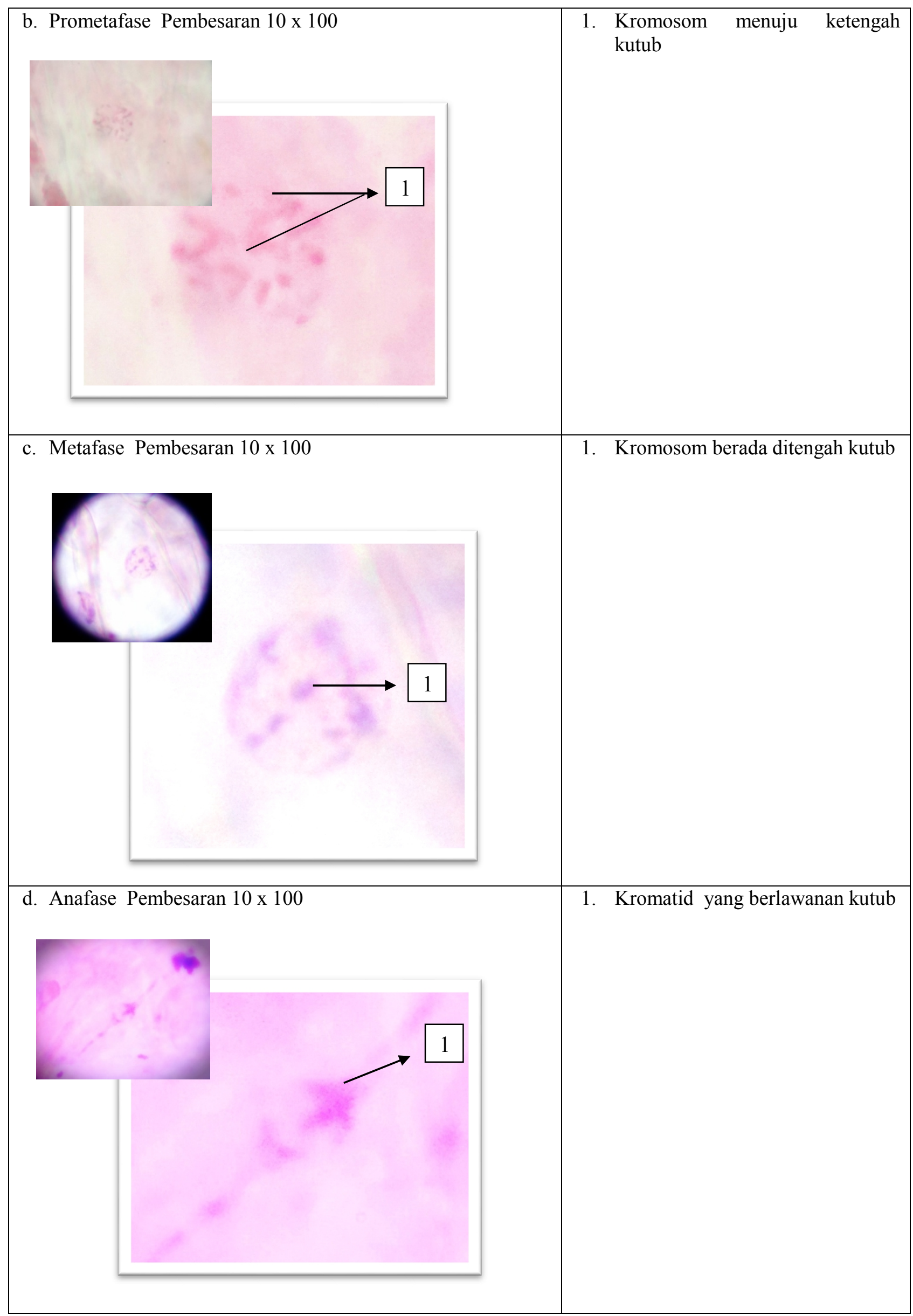




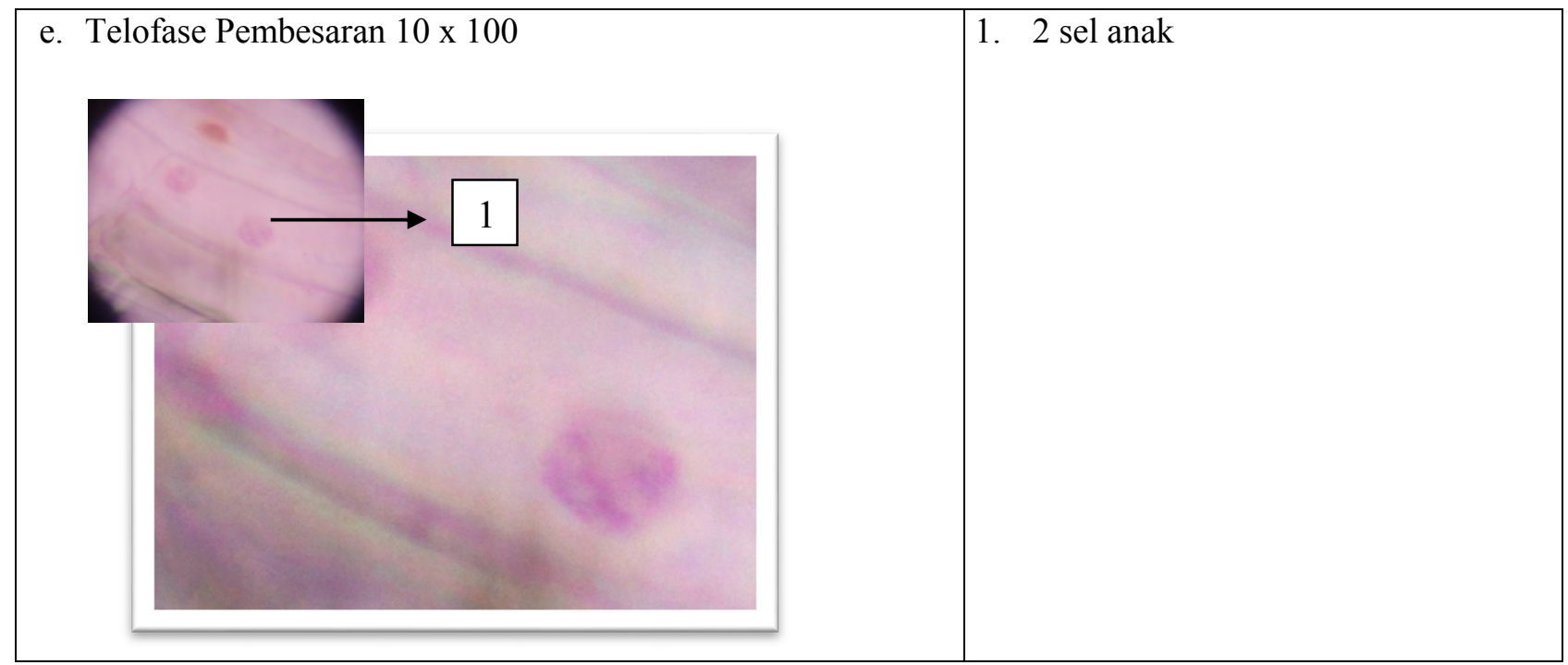

Tabel 2. Waktu Pengamatan Fase-fase mitosis pada markisa ungu ( $P$. edulis) varietas edulis yang dimulai pada pukul 09.00 WITA

\begin{tabular}{llc} 
No. & Fase-fase pembelahan mitosis & Waktu Pembelahan (menit ke-) \\
\hline 1. & Profase & 5 \\
\hline 2. & Prometafase & 80 \\
\hline 3. & Metafase & 154 \\
\hline 4. & Anafase & 227 \\
\hline 5. & Telofase & 317 \\
\hline
\end{tabular}

\section{PEMBAHASAN}

Mitosis merupakan pembelahan sel yang dapat menghasilkan 2 sel anak yang identik dengan induknya. Mitosis pada tanaman terjadi selama 30 menit sampai beberapa jam (Crowder, 2006). Proses pengamatan mitosis $P$. edulis dilakukan dengan menggunakan mikroskop Binokuler "Primo Star Zeiss". Proses pembelahan sel $P$. edulis terdiri dari profase, prometafase, metafase, anaphase dan telofase.

\section{Profase}

Menurut Suryo (2008), pada tahap profase benang-benang tampak memendek sehingga terlihat tebal dan menjadi kromosom. Fase profase pada preparat akar $P$. edulis menunjukkan sel terihat terpisah dengan sel lainnya dan pada sel tersebut terlihat adanya kromatid yang menyebar dan tebal. Fase profase ini sendiri terlihat pada menit ke-5 atau pada pukul 09.05 WITA pada saat pengamatan pertama.

2. Prometafase

Pada preparat akar $P$. edulis fase prometafase ini terlihat pada jam 10.20 WITA, atau pada menit ke-80 setelah pengamatan pertama. Menurut Khalifah (2013), Fase prometafase merupakan fase awal dari metafase. Waktu prometafase pada beberapa tanaman berbeda-beda setiap spesies. Pada penelitian lain fase prometafase pada Cabai rawit (Capsicum frutescent) varietas cakra putih ditemukan pada jam 10.30 WIB (Tricahya, 2012). Sedangkan waktu prometafase pada jeruk nipis dan jeruk purut banyak ditemukan pada jam 08.00 WIB (Arisuryanti dkk, 2007).

3. Metafase

Pada preparat akar $P$. edulis, fase metafase terlihat pada menit ke-154 atau pada pukul 11.34 WITA setelah pengamatan pertama. Menurut Susanto dkk (2011), pada fase metafase benang spindel telah terbentuk dan kromosom terlihat menebal dan berada pada bidang tengah sel (bagian ekuator), pengamatan pada fase ini paling mudah dilakukan karena pada tahap inilah kromosom paling jelas terlihat.

4. Anafase

Pada preparat akar $P$. edulis, fase anafase terlihat pada menit ke-227 atau 
pada pukul 12.47 WITA setelah pengamatan pertama. Menurut Elrod (2002), Selama anaphase, kromatidkromatid memisah di bagian sentromer dan tertarik ke kutub-kutub yang berseberangan.

5. Telofase

Pada preparat akar P. edulis, fase telofase terlihat pada menit ke-317 atau pada pukul 14.17 WITA setelah pengamatan. Menurut Elrod (2002), pada fase telofase, masing-masing set kromatid yang memisah berkumpul pada kedua kutub sel dan kromatid tersebut kini berubah menjadi kromosom.

Menurut Rindyastuti dan Daryono (2009), lama fase mitosis secara khusus diatur oleh gen dan bervariasi antara spesies yang satu dengan spesies lainnya, antara organ yang satu dengan organ yang lainnya dalam satu spesies, bahkan antara tipe sel satu dengan tipe sel yang lainnya. Waktu pembelahan mitosis $P$. edulis varietas edulis pada penelitian ini terlihat pada jam 09.00-15.00 WITA. Pada penelitian yang dilakukan sebelumnya pada beberapa spesies berbeda menyebutkan bahwa waktu mitosis papasan I (Coccinia grandis (L) Voigt) dimulai pada jam 08.00-11.30 (Rindyastuti dan Daryono (2009), jeruk nipis (Citrus aurantifolia) pada jam 08.00-08.30 WIB, jeruk purut (Cirus hystrix DC) pada jam 08.00-09.30 WIB (Arisuryanti dkk, 2007). Namun berbeda dengan papasan II yang waktu mitosis dimulai pada jam 08.30-09.30 WIB, 11.00-12.00 dan 14.00-14.30 WIB (Rindyastuti dan Daryono, 2009), begitupun dengan waktu mitosis aktif pada tomat varietas Berlian, varietas Intan (Darmawan, 2010) dan pada cabai rawit (Capsicum frutencent) varietas cakra putih (Tricahya, 2012) yaitu pada jam 08.30 WITA. Sedangkan pada bawang putih (Allium sativum L.) diperoleh waktu pembelahan optimum pada jam 09.00 (Suminah, 2002).

Pada tanaman mata kucing (Dimocarpus malesianus) menunjukkan bahwa waktu mitosis aktif tanaman mata kucing antara pukul 07.00-09.00 WITA, (Hardian et.al., 2011). Sedangkan pada kacang kapri (Pisum sativum L.) waktu pembelahan optimum diperoleh pada jam 22.00 (Suminah, 2002).
Beberapa tanaman aktif membelah pada pagi hari berkisar antara jam 07.00-12.00 WITA, namun pada kultivar tertentu diperoleh waktu pembelahan optimum pada malam hari pada jam 22.00. Pada $P$. edulis, sel aktif membelah pada pukul 09.00 sampai jam 15.00 WITA. Pembelahan sel pada tanaman berbedabeda karena memilki morfologi yang berbedabeda pula, seperti pada $P$. edulis yang memiliki kulit biji yang keras sehingga proses perkecambahan pun terbilang lama, akar muncul pada 1-2 bulan setelah penanaman.

Bahan utama yang sering digunakan pada penelitian mitosis adalah akar yang masih muda, asam asetat $45 \%$ yang bertujuan untuk mempertahankan kesegaran agar P.edulis, HCL $1 \mathrm{~N}$ dengan tujuan untuk melisiskan lamela tengah, dan aceto orcein yang bertujuan untuk mewarnai kromosom. Pada akar muda tersebut terdapat jaringan maristematik yang masih aktif untuk membelah. Selain itu juga digunakan kolkisin sebagai reagen untuk memperjelas pengamatan fase mitosis. Menurut Suminah (2002), induksi kolkisin merupakan mekanisme yang sering digunakan untuk mendorong terjadinya mutasi, sehingga terjadi perubahan bentuk, ukuran dan jumlah kromosom (pengurangan dan penambahan) sehingga pengamatan pun lebih mudah dilakukan. Dalam penelitian Induksi Poliploidi Bawang Merah (Allium ascalonicum L.) dengan pemberian kolkisin perubahan yang terjadi ditandai secara visual dengan membesarnya ujung akar (Jw: jendulan).

Pada penelitian ini, hasil yang diperoleh tidak begitu jelas pada setiap fase dikarenakan proses pewarnaan pada ujung akar P.edulis yang kurang lama. Menurut Setiawan (2000), Setiap kultivar tanaman memiliki daya serap pewarna yang berbeda-beda pada setiap kromosomnya, sehingga dibutuhkan waktu yang lebih lama untuk penetrasi. Hal ini sangat dipengaruhi jenis tumbuhan. Perbedaan tanggapan terhadap reaksi warna ini menunjukkan perbedaan gen dan protein yang dihasilkan.

Aceto orsein sangat cocok untuk ujung akar karena penetrasinya cepat, serta tahan lama. Nurjannah (2011), pewarnaan pada Akar planlet anggrek Phalaenopsis gigantea, 
Phalaenopsis fasciata dan Phalaenopsis schilleriana dilakukan dengan menggunakan aceto orcein $2 \%$ selama 24 jam pada suhu $5^{\circ} \mathrm{C}$. Sedangkan pada tanaman pacar air (Impatiens balsamina L.), pewarnaan akar selama 5 menit (Wiendra, 2011).

Pembuatan preparat akar $P$. edulis pada penelitian ini dilakukan dengan metode squash (pencet). Kualitas squash sangat menentukan kualitas preparat. Squash yang baik menghasilkan preparat yang hanya terdiri dari selapis sel, terpisah-pisah, tidak tumpangtindih, tidak terpecah-pecah dan tidak terdenaturasi. Squash dilakukan dalam media gliserin. Gliserin bersifat kental dan licin, sehingga memudahkan proses squash serta sulit menguap sehingga mampu menjaga kesegaran bahan.

\section{KESIMPULAN}

Fase-fase mitosis pada penelitian yang dilakakukan telah ditemukan fase profase, prometafase, metaphase, anaphase dan telofase pada preparat akar markisa ungu (Passiflora edulis) varietas edulis Sulawesi Selatan yang menggunakan perlakuan (perendaman kolkisin).

Waktu pembelahan mitosis pada tanaman markisa (Passiflora edulis) varietas edulis Sulawesi Selatan terjadi pada jam 09.00 sampai jam 15.00 WITA. Fase profase terlihat pada jam 09.05 WITA atau pada menit ke-5 setelah pengamatan, fase prometafase terlihat pada jam 10.20 WITA atau pada menit ke- 80 setelah pengamatan pertama, fase metafase terlihat pada jam 11.34 WITA atau pada menit ke-154 setelah pengamatan pertama, fase anafase terlihat pada jam 12.47 WITA atau pada menit ke-227 setelah pengamatan pertama, dan fase telofase terlihat pada jam 14.17 WITA atau pada menit ke-317 setelah pengamatan pertama.

\section{DAFTAR PUSTAKA}

Arisuryanti T, Rahmawati, Kartina AK. 2007. Studi Kromosom Jeruk Nipis (Citrus aurantifolia (Chritsm.) Swingle) dan Jeruk Purut (Citrus hystrix DC). Berkala Ilmiah Biologi. vol 6(2): 107 - 112.
Crowder LV. 2006. Genetika Tumbuhan. Yogyakarta: Gadjah Mada University Press.

Darmawan G. 2010. Karakterisasi kromosom Tomat (Lycopersicum esculentum Mill) Varietas Berlian dan Varietas Intan. [Skripsi]. Yogyakarta: UIN Sunan Kalijaga.

Elrod S and Stansfield W. 2002. Genetika Edisi Keempat. Jakarta: Erlangga.

Karsina FH, Silalahi FH, Manshur A. Eksplorasi Dan Karakterisasi Plasma Nutfah Tanaman Markisa. 2007. J.Hort. 17(4):297-306.

Nurjannah IS. 2011. Pengaruh Konsentrasi Kolkisin Pada Beberapa anggrek alam (Phalaenopsis sp). [Skripsi]. Surakarta: Universitas Sebelas Maret.

Novel SS, Nuswantara S, Syarif S. 2010. Genetika Laboratorium. Jakarta: Trans Info Media.

Rindyastuti R dan Daryono BS. 2009. Identifikasi Papasan (Coccinia grandis (L.) voigt) di Tiga Populasi di Yogyakarta. Jurnal Biologi Indonesia. vol 6 (1): 131142.

Rukmana R. 2008. Usaha Tani Markisa. Yogyakarta: Kanisus.

Suminah S dan Setyawan AD. 2002. Induksi Poliploidi Bawang Merah (Allium ascalonicum L.) dengan Pemberian Kolkisin. Biodiversitas. vol 3 (1): 174180.

Setyawan AD dan Sutikno. 2000. Karyotipe Kromosom pada Allium sativum L. (Bawang Putih) dan Pisum sativum L. (Kacang Kapri). Biodiversitas. vol 2 (1): $20-27$.

Sunarjono H. 2008. Berkebun 21 Jenis Tanaman dan Buah. Jakarta: Penebar Swadaya.

Suryo. 2007. Sitogenetika. Yogyakarta: Gadjah mada University Press.

Susanto HA. 2011. Genetika. Yogyakarta: Graha Ilmu.

Tricahya E. 2012. Karakterisasi Kromosom Cabai Rawit (Capsicum frutescens) Varietas Cakra Putih. [Skripsi]. Yogyakarta: UIN Sunan Kalijaga. 
Wiendra NM, Pharmawati M, Astiti NP. 2011.

Pemberian Kholkisin Dengan Lama

Perendaman Berbeda Pada induksi
Poliploid Tanaman Pacar air (Impatiens balsamina S.). Jurnal Biologi XV Universitas Udayana. vol 1 (1):9-14. 